\title{
Phenomological Happiness of the History and Geography Teacher in
} Rural

\author{
Yone Vilchez Cisneros ${ }^{1}$, Doris Fuster- Guillen ${ }^{2}$, Roger Pedro Norabuena Figueroa ${ }^{3} \&$ Reyna Luisa Cruz Shuan $^{3}$ \\ ${ }^{1}$ Universidad San Ignacio de Loyola, Perú \\ ${ }^{2}$ Universidad Privada San Juan Bautista, Perú \\ ${ }^{3}$ Universidad Nacional Mayor de San Marcos, Perú \\ Correspondence: Yone Vilchez Cisneros, Universidad San Ignacio de Loyola, Perú.
}

Received: August 20, 2020

Accepted: October 15, 2020

Online Published: November 2, 2020

doi:10.5430/ijhe.v9n9p41

URL: https://doi.org/10.5430/ijhe.v9n9p41

\begin{abstract}
The purpose of this research was to describe, analyze and interpret the essence of the experience lived by teachers of the specialties of History and Geography in Huanca Sancos - Ayacucho. Reflective and empirical methods of hermeneutical phenomenology were developed; the latter is responsible for addressing reality based on the subject's consciousness in understanding the meaning of what has been experienced; research was oriented from the qualitative approach and interpretive paradigm. The information was obtained from a sample made up of teachers who narrated their experiences through anecdotes. Close observation and a conversational interview were also used as instruments and techniques. The analysis and interpretation of the information allowed to discover individual and group meanings such as happiness, reflection, satisfaction, and tranquility; thus building as a general thematic unit of this study: the happiness of the teacher, understood as fullness, well-being and satisfaction; it is actually the source of all pedagogical transformation. To conclude, it can be stated that the study has the character of stimulation and satisfaction in the practice of pedagogical happiness as a habit that leads to making thinking more flexible and discovering better options for a change
\end{abstract}

Keywords: teacher happiness, reflection, tranquility, hermeneutical phenomenology

\section{Introduction}

Education is the engine of development in every society, because through it, multiple needs and current difficulties can be overcome. Roa (2017) considers it a strategic and priority component of the country's human, social and economic development, as well as an essential tool for the constitution of an autonomous, just and democratic society. The teacher plays a leading role by acting as a facilitator, guide and counselor so that students can develop their abilities and, in this way, be able to face favorable and unfavorable circumstances, learning that will serve them for life, since whoever has the information has the possibility of deciding and facing problems. Viñals and Cuenca (2016) point out that a teachers, due to his or her multiple functions, is often referred to as organizer, guide, generator, companion, coach, learning manager, advisor, facilitator, tutor, dynamizer or advisor.

Teachers live various experiences during the teaching-learning process; they experience important and valuable situations that will serve to improve their work in the classroom. Espinoza, Tinoco and Sanchez (2017) state that teachers perceive the classroom as the place where they research, experiment, model, share ideas and make decisions. Besides, their professional and personal competence is compromised during their work; Guzmán (2018) states that teachers in their daily work compromise a set of attitudes, aptitudes, dispositions, actions, resources and time, for which the valuable contribution of experiences to improve educational quality is evident. It is therefore confirmed that experience is important, since it permits knowing the true situation of the educational reality, the difficulties of teachers in the classroom, and their strengths. Each situation has its peculiarities, features, characteristics and, by systematizing it, errors are overcome because, from these experiences, it is possible to improve the educational work. The experiences allow teachers to gain more experience to face problematic situations with great efficiency and success. Bezanilla, Poblete and Fernandez (2018) point out that experience allows everyone to analyze and reflect on reality in order to question and understand it objectively.

It is important to analyze the experiences of teachers taking into account the phenomenological significance they represent. Van Manen (2014) points out that in order to study a pathetic experience, it is necessary to employ both 
cognitive and non-cognitive methods such as the situational, incarnated, action and relational methods that allow the researcher to address the meanings of a lived experience. Pathic knowledge is present in one's actions, in the places where on is, in the body and in the relationships with others. In this non-cognitive or paternal dimension, the participation of poetic language can be observed; one takes care of how it is written (Fuster, 2019). Epiphany refers that knowledge must provoke a transformation so that its deep meaning makes an appeal to the reader's self. Epiphany is the final writing of the research that makes it possible to enter, with greater depth and originality, with intuitive or inspired understanding, through the ethics and values of life's commitments and practices. Van Manen (2014) states that the text should provoke a deeper transformative effect and make a construction of the reader's self. He refers to the phenomenological text linked to the happiness of the teacher, an emerging category in this research. This study refers to the happiness of Ayacucho's teachers working in very wild places. Actually, they must ride on mules to educational institutions where there are no communication medi; these are factors that limit teachers in their work. On top of this, there is the critical economic situation of teachers and students, who in their great majority lack and are unaware of technological advances. In spite of the individual difficulties of the teachers in Los Andes de Huanca Sancos, in the region of Ayacucho, they show feelings of happiness with much pleasure and satisfaction at the moment of carrying out their activity in the classrooms.

Garcia and Jover (2019) consider that happiness should be the fundamental goal of education, something that both students and teachers must discover. The happiness of teachers in their educational work can be explained from several perspectives; from the social philosophical perspective, two types of meanings related to happiness predominate. On the one hand, happiness is considered as a good condition of life and, on the other hand, happiness is considered as the experience of good quality of life. Dudley (2018) points out that the final cause of the effort of human beings to achieve happiness arises from progress towards the goal of achieving their best possible condition for the longest time. In contrast, from the moralistic philosophical perspective, happiness means good action; that is, psychological well-being or happiness is a virtue. According to Bosch (2019), good actions originate a gratifying feeling.

From the field of social sciences, happiness is a subjective enjoyment of life, one can like a certain situation of life, although one can suffer tensions too; for example, a teacher feels happy when interacting with students even if an unpleasant episode happens during the class. Veenhoven (2001) points out that happiness is the evaluation of the degree of quality of life as a whole; that is, when the life he leads is to his liking. At the same time, Veenhoven (2005) also points out that happiness is part of the personal experience and results from the diagnosis of each person's life. As for the happiness of History teachers, it is fundamental to seek their psychological well-being since they are the motor of education. Research should focus on the analysis and understanding of teachers from the subjective point of view, since it will allow researchers to know, understand and support teachers so that they can develop their work effectively and achieve their happiness. Morana, Fínez and Fernández (2017) affirm that high levels of happiness are associated with advantages for mental health with more adaptive dispositions and personality traits; in conclusion, satisfaction is the main indicator of well-being (Sánchez, García, Valverde and Pérez, 2014). Happiness is an emotional state of high satisfaction in the life of teachers when they establish friendly relationships with students (Rivera, Cruz, \& Muñoz, 2011); high life satisfaction is associated with adaptive coping strategies in the learning process aimed at solving problems (Diener \& Chan, 2011). Happiness, understood as a total evaluation of oneself and in relation to the emotional state over a long period of time, generates satisfaction during human existence (Hernández, 2002).

Domínguez and Ibarra (2017) point out that teachers practice the positive psychology that explains the strengths and virtues that human beings possess to get through difficult situations. Happiness is a feeling that human beings seek during their existence; therefore, it has motivated a great number of inquiries and philosophical reflections. Happiness is a positive emotion known as subjective well-being, psychological well-being, bliss and positive affection. For Muratori, Zubieta, Ubillos, González and Bobowik (2015), it includes notions such as subjective well-being, psychological well-being, hedonism and eudemony, but also health or personal growth. Fernández, García, Jiménez, Martín and Domínguez (2011) affirm that happiness is a positive emotional state of the individual, and it is manifested by feelings of well-being and satisfaction thanks to the achievement of work, academic, social, family and professional goals that have great meaning in people's lives.

The subjective well-being of Ayacucho's teachers is expressed through their joy, well-being, and satisfaction when they interact with students; this is important because the positive emotional state will be reflected in the students' learning. Obviously, teachers feel more motivated and more willing to work; they feel strengthened, and this results in significant behavioral changes in the individual. Auné, Abal and Attorresi (2017) mention that happiness, as a positive feeling, allows one to look at the past, present or future with optimism. In the experiences of teachers, one can capture happiness, understood as a feeling of pleasure; obviously, all this is equivalent to the degree to which individuals experience satisfaction. This conception of happiness is similar to satisfaction in life or self-realization. Positive 
emotions such as feelings of happiness, joy and satisfaction are decisive during the teaching act, because the teacher, by showing an attitude of happiness, passes on this feeling to students. Colomo (2015) points out the need for teachers to teach people to be happy, to have power and control over their own lives, to guide their thoughts, and to reflect on their emotions in order to improve their quality of life.

\section{Method}

For the study, an interpretative or naturalistic paradigm was considered, centered on obtaining meanings through interpretation, analyzing their beliefs, studying their intentions, motivations and other characteristics of the educational process, these are not directly visible, and they are not the object of experimentation. The qualitative approach was also used since education is a social phenomenon that seeks to understand, analyze and reflect on the experiences of educational actors. The phenomenological method was used, guided by the two principles: epoché which means to abstain or withhold (Villanueva, 2012) and reduction, centered on perceiving and describing the particularities of consciousness, and understanding in a systematic way how this subjective world is constituted (Fuster, 2019).

The study was developed through phases. The first phase is that of clarification of presuppositions, in which, according to Martínez (2004), the researcher must free himself from his prejudices, based on customs, traditions, religion, among others, of the reality that surrounds him. Scientists must free themselves in order not to alter the results, i.e. leaving aside their beliefs in order to have freedom of ideas.

In the second phase, which has to do with collecting the lived experience, the collection of the experiences of the teachers in written form. These anecdotes prioritize experiences as they occurred, avoiding any kind of clarification or causal explanation such as: "I think it should be so..."; generalizations such as: "I guess it should be..." or interpretations of an abstract nature such as: "you can tell...". These are complemented by conversational interviews. After that, the researcher proceeds to read and identify some parts that are not clear or have gaps or are simply doubts; with such doubts, the researcher goes back to the teachers and gathers the complementary ideas of the writing. Then, based on this activity, the respective rewriting is done, expanding the anecdote, in turn comparing it with the previous version, and once the narration of the experience is finished, the meaning should be highlighted, leaving aside the secondary ideas, but always respecting the teachers' ideas.

In the third phase, which consists of reflecting on the lived experience, the respective thematic analysis is made (Ayala, 2008 and Van Manen, 2003). Van Manen (2003) points out that, in this phase, the aim is to determine the sentence that seeks to obtain the meaning of the paragraphs under study; then, a linear analysis of the corresponding paragraphs is made and sentences are sought that capture the idea and the essential meaning of the experience. At the same time, a transformation of the language initially used is made, constituting a hermeneutic work, in which the most sensitive and appropriate paragraphs for the corresponding interpretation are collected (Van Manen, 2014). The researcher concentrates on reflection and interpretation of the lived experience. An imaginative effort is necessary to obtain a hypothetical suppression of the essential themes; besides, the reflection is oriented to detect prejudices, beliefs and customs present in the interpretative phase. Once interpreted, the ideas are submitted to self-criticism in order to discover their political or ideological position (Fuster, 2019).

The fourth phase, which consists of writing-reflecting on the lived experience, follows the procedure that after the reflection process is completed, the phenomenological text is written; for this purpose, the entire findings of the study are collected. About this, Van Manen (2003) affirms that the purpose of the study of a phenomenological hermeneutic character is to make a description as the facts and phenomena or lived experiences are given; it expresses the meaning of cognitive character, i.e., it must manifest the semantic meanings of the words. A phenomenological text is written comprising an individual physiognomy and a group physiognomy. The elaborated text expresses the meaning of a cognitive and expository type that allows the reader to understand the epiphany of meaning; that is to say, the phenomenological text must express a transforming effect and the meaning must call the attention of the reader's self (Fuster, 2019).

As for the sample used, it was made up by rural education teachers in the specialty of History, chosen by the snowball sampling techinque, because teachers were identified as achieving significant learning in their students. Teachers were assigned pseudonyms as the educator, the sociologist, the pedagogue, the trainer, and the speaker, focusing on their characteristics at the time of action. In the collection of their writings, the technique of close observation and conversational interview was used. In regard to this, Van Manen (2014) points out that close observation consists of having the subject of study as close as possible, while taking a state of alert of a hermeneutic nature, that consists of taking a step into the past and, from there, reflecting on the meaning of those facts. The conversational interview consists of collecting data from a story about any experience. In this regard, Van Manen (2003) states that conversational interview methods involve the action of gathering or collecting data, with respect to the story of a 
valuable experience, out of which something is obtained, and that something obtained is not quantifiable. The instruments used are the testimony card and personal anecdotes of the teachers.

\section{Results}

Phenomenological happiness expressed in satisfaction is translated into a feeling of happiness or psychological well-being of the teacher, which becomes concrete in the joy and satisfaction reached by the transformation of attitudes, behaviors and study habits in students, after long and very thoughtful learning sessions. These sessions are prepared with the only purpose of making students better people and, at the same time, making them feel very happy. For this reason, the experiences inside and outside the classrooms generate feelings of joy, which constitute the indispensable component to generate psychological well-being in all subjects of education.

I felt the satisfaction of having achieved a transformation in John's attitude and behavior because, practically, he was already a regular visitor to the school library, doing his homework, keeping up with his notebooks, and doing his homework well in advance. (Paragraph 14, the speaker, UT.4)

From that date on, the student changed his attitude and today he feels very grateful to me. I also feel satisfied and happy with that change because, as teachers, we expect children to standout and learn; I was happy to see that he was doing his work and was no longer bothering his classmates; for me it was a joy because the boy improved and changed. Now as a former student, when I meet him on the street or at a party, he tells me "thank you because you made me change my behavior." (Paragraph 15, the speaker, UT.4)

Seeing that the student has changed a lot, I felt happy, I felt good and satisfied, with more desire to work. I motivated myself to work with more strength, and I felt strengthened, which constitutes an important experience in my professional development within the process of teaching and learning. It also serves me a lot to put this into practice with other students who have similar problems regarding their learning process. (Paragraph 12, the pedagogue, UT. 3)

Authentic phenomenology-oriented happiness is a product of self-realization, personal growth and the practice of values by teachers and students within the educational endeavor. The feelings of happiness or authentic well-being demonstrated arise from the achievement of educational objectives and purposes; the goals achieved generate happiness and psychological well-being, achieved with the use of multiple strategies oriented to attend the diversity of learning rhythms.

When the day came to hand in the work, John presented his paper and explained it to me. He organized the information in a detailed way and it came out very well; so he was very happy because this had meant a challenge for him, and in this opportunity he had to do it himself. I had previously stimulated him, saying that itwas not so difficult to do, and I could see that he felt happy. He had the feeling of wanting to do more work, and he learned to handle information. He enjoyed doing research and he could pass, ending the term with good grades. (Paragraph 11, the speaker, UT. 3)

When I arrived to the beautiful land of Huanca Sancos, I went to the glorious educational institution Los Andes, where I could observe the amount of students, and I was amazed. That day I had classes with 4th B class students; but I arrived after the break. It was really beautiful because I felt totally happy and, at that moment, I was convinced of my condition as an educator, and I felt that my dream had been fulfilled. (Paragraph 1, the educator, UT. 1)

Seeing that the student is dedicated, I feel happy because these will be future citizens and Peruvians who are different, even though there are still some young people who are immature in their thinking; however, there are thirteen, fourteen and fifteen year-old young people of who have adult thoughts, and this favors the institution and the community. (Paragraph 16, the educator, UT.1) 
There is a manifestation of an interested and authentic altruism for the achievement of happiness, reflected in the generosity, dedication, recommendation and dedication of the teacher, which provokes changes in the attitude of students, above all, for those considered as "difficult cases". Overcoming irresponsible behaviour in many of them, diminishing the negative attitudes of students who carry on their shoulders the weight of a painful family past actually generated feelings of happiness and subjective well-being in students. As a matter of fact, happiness is also freedom, but it cannot be confused with debauchery, for they express themselves with freedom, but respecting the opinions and beliefs of others.

I felt lke I had made a significant change in the student's attitude and behavior because he was already visiting the school library regularly, he was doing his homeworks, updating his notebooks, and doing his homework well in advance. (Paragraph 14, the speaker, UT.4)

In order to gain the student's trust, I spoke to him as if he were an older brother, I asked him to stop behaving irresponsibly and to comply with his activities. He told me that the lived alone with his siblings, somewhat abandoned, Apparently that factor was what determined his attitude because he had too much freedom, and besides he had no control at home. He added that his parents came to visit him only once a month during the year. I took advantage of the circumstance to tell him that I had also gone through the same situation, and I told him how to organize his time. Then, he began telling me about the many sad experiences he had gone through because of his parents' absence; Under those circumstances, he fell into tears, and the truth moved me a lot; that's why, I became friends with him so that I could support him emotionally. (Paragraph 5, the pedagogue, UT. 1)

After following my recommendations, he started to change; but that change has been slow and gradual; he began to show more responsibility for his work, his presentations. He was already doing his work in advance, and he would tell me "teacher, we already have the material to make the presentation", the truth is that he had never done that before, and I felt happy because he showed another attitude. (Paragraph 7, the pedagogue, UT. 3)

One day, as she continued being irresponsible, I felt angry because I had already given her several opportunities; however, she was still in the same situation. So, I decided to stay in the classroom to talk to her at the end of the class. Shewanted to go out for the break, but I did not allow her to. When I asked her the reason for her actions and her failure to comply with tasks, she sadly answered that she liked dance, and that in the evenings she was participating in a dance workshop< she said prioritized what she liked most over her duties. Then, she apologized fand asked me for a few days to catch up on her homeworks and updating of her notebook. Her lack of responsibility was not only in the area of History, but also in most of the course subjects. (Paragraph 07, the trainer, UT.1)

Two weeks after, I revised the notebooks, and I noticed that hers were updated and well presented; each task was ordered and with drawings related to the topic (dancing), I could see then that Angela felt happy, you could see it in her face that she wanted to jump because of joy. Notwithstanding, she did delay to hand in her notebook not only in my area, but also in the other areas, and she focused on doing her work. Each teacher congratulated her and she motivated herself to make a bigger effort. (Paragraph 11, the trainer, UT. 3).

The extroverted personality and its link with happiness is demonstrated when the teacher experiences and shows feelings of joy, satisfaction and happiness that result from the change of attitude and the extroverted behavior of many students; he or she faces the extrovert with patience and understanding, making it clear that it does not mean disrespect.

He was a slim-looking student of short height; he was very restless all times. He was a spoiled boy who showed his misbehavior in the classroom because he was never quiet. In class time he would show his mischievous behavior, and when scolded, he would ignore it. He stopped misbehaving just for a little while, but then he would continue. Sometimes obeyed when I called his attention, but only rarely, as he was a rebel. One afternoon, he 
surprised me when he told me he wanted to be my student forever, he said because I could understandd him. (Paragraph 2, the speaker, UT. 1)

I could see that Pauca felt good because he was calmer, there were changes in his behavior, he seemed to be more calmed. He he was paying more attention in class, concentrating and collaborating; but always outgoing, liberal and restless. He is developing some changes; I see him participating more in cultural events. (Paragraph 11, the pedagogue, UT. 3)

Angela was too restless and always bothered her classmates; sometimes she would sit in front; other times at the back of the classroom, sometimes singing and mocking the teacher's actions. Any movement I made during class was a reason for her to imitate me; when I turned around, I caught her already doing the same movements or the same gestures and her classmates noticed everything she was doing and started laughing. She did exactly the same thing with other teachers. She would take her classmates' belongings; sometimes she would hold a classmate's hand; in other circumstances, she would punch or slap them; that is, she was too restless, and really, there was no way you could control her. Sometimes, I would even get tired of being there. (Paragraph 03, the trainer, UT.1)

On the other hand, the introvert personality and its link with happiness can be observed when showing feelings of satisfaction. Of course, students do not often show this happiness; however, during class time they feel happy.

Initially, the student did not participate much in class, he was almost always silent. In fact, I did not really know the student, but one day he asked me: "Who do you recommend me to read? Tell me about a Peruvian philosopher". I could inmediately notice that he was a good reader. I congratulated him and asked: "How come you master the course?" And he told me that his father insisted on his reading and talked him into it it telling him he would be a lawyer. Then I asked: "How are you doing in the number courses", he told me that in numbers almost nothing.It was precisely then that I told him that every subject has to be given its due importance. (Paragraph 8 , the educator, UT. 3)

In the Luis Enrique Galvan Candiotti school in Laramate, in 1994, a fifth grade student whose surname was Sarmiento Gallegos, was a quiet and silent student (introverted), he didn't show any political or ideological tendency to think he was related to seditious groups. One morning I stumbled and I could see a big smile on his face; I felt so happy (Paragraph 01, the sociologist, UT. 1)

As for interpersonal relationships and phenomenological happiness, the feeling of happiness or psychological well-being centered on the meaning of what is lived either inside or outside the classroom, is concretized in the socialization between students-teachers, students-students, and teachers -teachers within the educational community. This is evidenced by the fulfillment of assigned tasks, by the pretensions and by the empowerment of students of their own academic performance. Because of all this, it is demonstrated that intertpersonal relatioships is an indispensable, relevant and important component of happiness in the educational process.

As John was already doing his assignments, his classmates congratulated him. Although some did not take any interest nor payed due attention to him, others told him "you were saved, congratulations, is that difficult?". Since the student had changed his behavior notoriously, he learned how to investigate and he liked it. (Paragraph 13, the speaker, UT.3)

In class, the first grade student raised his hand to participate and gave his opinion about his words by giving examples. He asked me the following question: "Professor, are there philosophers in Ica?" "Yes", I replied, "for example, there is Professor Juan Manuel Cordova, who published books"; he got excited and said he wanted to be like him. (Paragraph 9, the educator, UT. 4) 
In the class sessions, the student felt motivated and participative, so he had several followers, admirers, imitators, who are trying to worry about studying more, preparing themselves, and trying to compete, because he constitutes a kind of focus that can give that initiative; this is something which I have also noticed in fourth grade "A" when one youngster speaks and gives his opinion, the other one does not stay behind, always refuting in the debates that I generate in the class session. (Paragraph 14, the educator, UT. 4)

Besides making friends with him, I looked for other strategies such as recommendations telling him that man becomes stronger when he does his own activities without his parents being there; I told him that when you are alone, you become more mature and prepared for any situation because life always brings challenges that we must face, and if you act this way, you will not have problems in the future because your future depends on you; but always practicing values such as responsibility. (Paragraph 6, the pedagogue, UT. 2)

His change towards a positive attitude was not only manifested in the classroom, but also outside of it with respectful greetings; he would say with more enthusiasm: "Professor, good morning". He would say that he felt more confident and at ease. (Paragraph 8, the teacher, UT. 3)

Angela's change in attitude was quite noticeable because, for example, when she entered the classroom, she would say, "Excuse me, Miss," She greeted me already before entering the classroom, something which she did not do before or used to do so inappropriately. (Paragraph 13, the trainer, UT. 3).

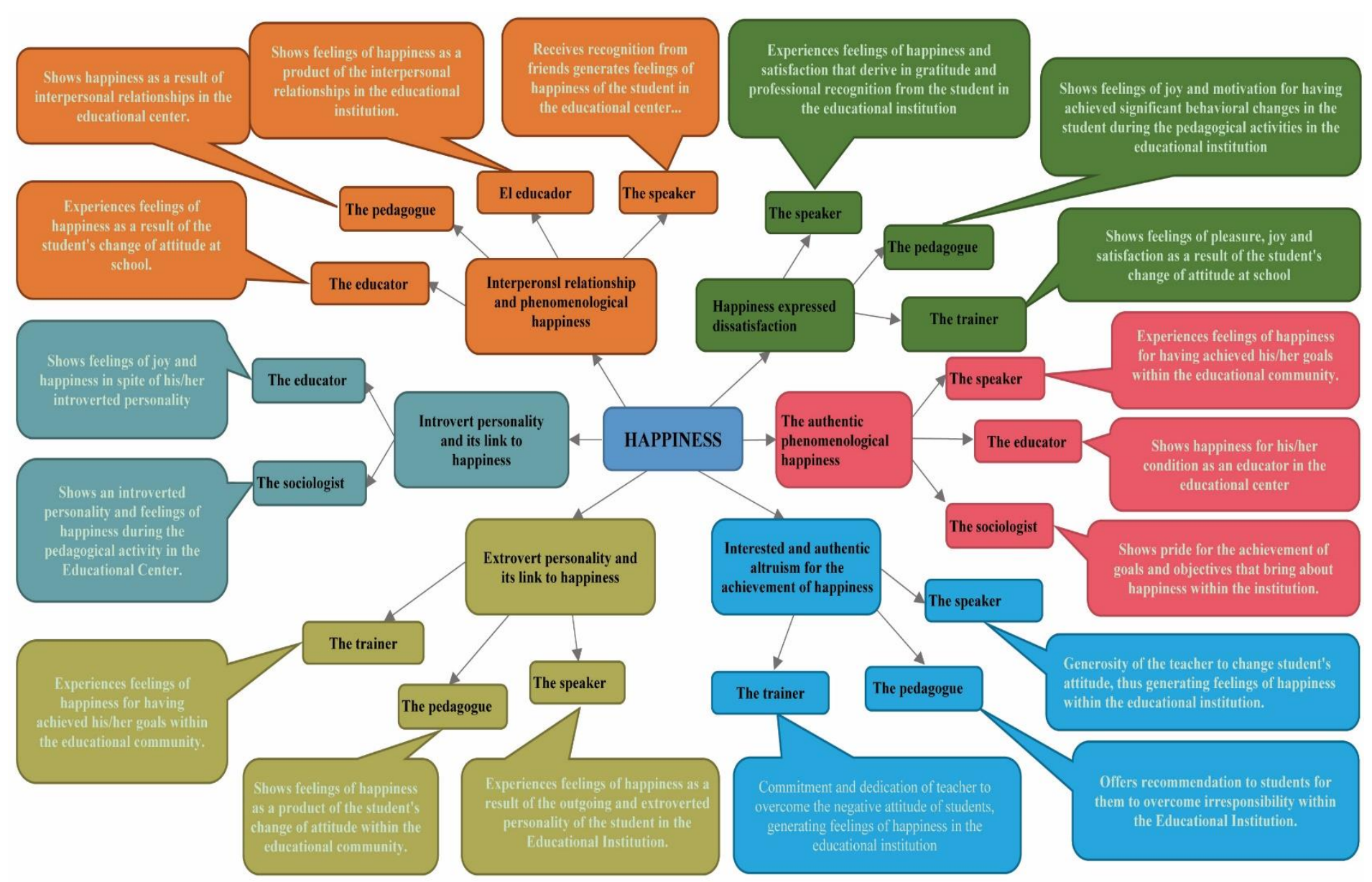




\section{Discussion of Results}

Regarding reflection as an ethical and philosophical process, the educational actors showed a reflexive attitude regarding the practice of values in their academic work, bringing along the happiness of the teacher in the reflexive processes of the actions performed. All this was corroborated by Lamas and Vargas (2016), who stated that they feel comfortable in all classes, that, when classes are over, they think about and program the next session with comfort and happiness, as they can insert strategies for each activity. Vielma and Alonso (2010) pointed out that when reflecting on the experience, giving it a direction and a sense from conscience at each moment, it is assumed as an ethical and philosophical process that is presented when a subject reflects on his own actions. On the basis of this, positive or negative actions can be identified. In this case, there is a coincidence with the research since, in the processes of reflection, the teacher expresses being happy because the goal of making students happy during the process of teaching and learning is fulfilled.

From a personal and professional perspective, satisfaction is presented as a gratifying situation that the educational actors experience as a result of their work; in the same way, in interpersonal relationships, feelings of joy and satisfaction are originated, and they have the capacity to live together generating satisfaction in the educational community. In this regard, Segura and Calderón (2019) pointed out that a positive school environment allows students to enjoy happiness, and that teachers play a very important role by using the tools and specialties necessary to define the students' learning purposes. This idea is reinforced by González (2013), who stated that interpersonal relationships and support through the praising given by all members of the educational community are important for professional development. All of this implies personal satisfaction that has an impact on their best consideration as professionals; there is great satisfaction with the training received as it meets the educator's expectations. It can be said that satisfaction, from the personal and professional perspective, is experienced by teachers when they feel gratitude and happiness as a result of their work with students, the daily effort to achieve the development of competences and skills, and the interpersonal relations with all the members of the educational community. Besides, teachers show their capacity of coexistence with colleagues, thus generating feelings of happiness and joy within the educational community.

Regarding the elements that intervene and bring about the happiness of the teachers, there were found extroverted and introverted students who, with the patience, confidence, empathy and assertiveness of their teachers, modified their attitudes and negative actions, which they presented as a justification for the extroverted. The teacher achieves happiness by diminishing disciplinary problems. Zumaeta, Fuster, and Ocaña (2018) pointed out that the happiness of the teacher is evidenced by the achievements obtained in attitude and behavior; this motivates the teacher to continue supporting students in difficult times. Margot (2007) mentioned that being happy implies that human beings are capable of achieving a balance that overcomes their contradictions and conflicts. If they want to be happy, they must not forget that happiness is the result of a conquest, first over themselves and then over a world in which they must take into account not only natural forces but also that of other human beings. Studies have corroborated this, and there is agreement with the stories recorded by research; if one overcomes adversities, limitations and lacks, one can be happy. Students need a substantial change and it will only be achieved if they are happy. Tschannen-Moran (2014) stated that in order to achieve their teaching and learning processes and objectives, educational institutions require close interdependence among their different members.

Teachers join the student's world through interactions that break the barrier, practicing interpersonal relationships, getting closer, providing confidence with a positive spirit, achieving happiness. Consequently, students and the members of the educational community can also be happy when performing their tasks and responsibilities. Actually, one must not forget that, in some rural areas, the teacher is the image or example for the community. García and Jover (2019) pointed out that happiness in education implies the substitution of vertical and hierarchical relationships to give way to interactions of a subjective and intersubjective type, while offering the opportunity to accompany each student in his or her personal and social development, thus building a democratic society. Regarding this, González (2013) stated that, thanks to the interpersonal relationships established with friends, family, partners and colleagues, positive emotions have been shaped; on the other hand, an interest in being remembered, in leaving a mark on their students, is revealed, all through the establishment of relationships in which affection, respect and love between teachers and students prevail. This interest in the emotional imprint is basically focused on what the teacher represents to the students as a person, and not so much because of methodological issues related to the teaching of certain subjects. Learning to be empathetic, seeing things with the eyes of a child and a teenager, helps to break down the barrier between teachers and students favoring a closer, more affective and memorable relationship. In all the cases under study, it was found that the initial socialization process has not been difficult in a general way, 
although a greater coordination and adaptation with the classmates is indeed evidenced, i.e., the more confidence and affection is shown, the quicker adversities are overcome and, therefore, the sooner the teacher will be able to find happiness.

\section{Conclusions}

Phenomenological happiness, expressed in satisfaction, is the feeling of pleasure and psychological wellbeing that constitutes an indispensable and relevant component of happiness, that becomes concrete in the joy of teachers in their educational activities. It occurs naturally, through experiences, feelings of joy, pleasure and satisfaction with even the simplest things. Authentic phenomenological happiness is the product of self-realization, personal growth and the practice of values on the part of teachers and students. Authentic happiness is an important component that, with the achievement of objectives and goals, generates feelings of psychological well-being in the subjects. The interested and authentic altruism for the achievement of happiness, is concretized in the convergence of the interested altruistic behavior and the authentic altruistic attitude of teachers and students, so it is a relevant component of happiness. As it is natural, the detachment, dedication, recommendation and dedication of the teacher provoke changes in attitude; overcoming irresponsibility and improving negative attitudes generate feelings of happiness and subjective well-being. Happiness is concrete and sustained in the attention of the extroverted students within the teaching-learning process; therefore, the extroverted personality is considered an important and relevant component of psychological well-being or happiness. Naturally, the teacher shows feelings of joy, satisfaction and happiness as a result of the change in attitude and the extroverted personality of the student within the educational center. The feeling of happiness is concretized in the socialization between students and teachers within the educational community, which is why it has been demonstrated that it is an indispensable, relevant and important component of psychological well-being.

\section{References}

Auné, S., Abal, F., \& Attorresi, H. (2017). Efectos del género y la educación en la felicidad en adultos argentinos. Liberabit, 23(2), 169-188. https://doi.org/10.24265/liberabit.2017.v23n2.02

Ayala, R. (2008). La metodología fenomenológica-hermenéutica de M. Van Manen en el campo de la investigación educativa. Posibilidades y primeras experiencias. Revista de investigación, 26(2), 409-430. Retrieved from https://revistas.um.es/rie/article/view/94001

Bezanilla, M., Poblete, M., \& Fernández, D. (2018). El Pensamiento Crítico desde la Perspectiva de los Docentes Universitarios. Estudios Pedagógicos, 49(1), 89-113. https://doi.org/10.4067/S0718-07052018000100089

Bosch, M. (2019). La felicidad en Aristóteles: fin, contemplación y deseo. SCIO. Revista de Filosofía, 16, 41-60.

Colomo, E. (2015). Cómo se educa para ser feliz? El papel del maestro en el desarrollo del alumno. Cuestiones Pedagógicas, 24, 59-74.

Diener, E., \& Chan, M. (2011). Happy people live longer: subjective well-being contributes to health and longevity. Applied Psychology: Health and Well-being, 3, 1-43. https://doi.org/10.1111/j.1758-0854.2010.01045.x

Domínguez, R., \& Ibarra, E. (2017). La psicología positiva: Un nuevo enfoque para el estudio de la felicidad. Razón y Palabra, 21(96), 660-679.

Dudley, J. (2018). Fundamentos físicos y metafísicos de la ética para Aristóteles. Areté, 30(1), 7-21. https://doi.org/10.18800/arete.201801.001

Espinoza, E., Tinoco, W., \& Sánchez, X. (2017). Características del docente del siglo XXI.OLIMPIA. Revista de la Facultad de Cultura Física de la Universidad de Granma, 14(43), 39-53.

Fernández, E., García, B., Jiménez, M., Martín, M., \& Domínguez, F. (2011). Psicología de la emoción. Retrieved from https://dialnet.unirioja.es/descarga/libro/535470.pdf

Fuster, D. (2019). Investigación cualitativa: Método fenomenológico hermenéutico. Propósitos y Representaciones, 7(1), 201-229. https://doi.org/10.20511/pyr2019.v7n1.267

García, A., \& Jover, G. (2019). Felicidad, educación y democracia en el pensamiento de Nel Noddings. Encounters, 20, 24-44. https://doi.org/10.24908/encounters.v20i1.12840

González, R. (2013). Aportaciones de la terapia cognitivo-conductual y la calidad de vida en el adulto mayor. En M.A. Cubillo-León y F. Quintanar-Olguín (comp.). Por una Cultura del Envejecimiento, 54-70. 
Guzmán, F. (2018). La experiencia de la evaluación docente en México: Análisis crítico de la imposición del servicio Profesional docente. Revista Iberoamericana de Evaluación Educativa, 11(1), 135-158. https://doi.org/10.15366/riee2018.11.1.008

Hernández, P. (2002). Los moldes de la mente. La Laguna: Tafor.

Lamas, P., \& Vargas, J. (2016). Los niveles de reflexión en los portafolios de la Práctica Pre Profesional Docente. https://doi.org/10.4995/redu.2016.5680

Margot, J. (2007). LA FELICIDAD. Praxis Filosófica, (25). https://doi.org/10.25100/pfilosofica.v0i25.3112

Martínez, M. (2014). Ciencia y arte en la metodología cualitativa. (2 ${ }^{\mathrm{a}}$ ed.). México: Trilllas.

Morana, M., Fínez, M., \& Fernández, E. (2017). Sobre la felicidad y su relación con tipos y rasgos de personalidad. Clínica y Salud, 28, 59-63. https://doi.org/10.1016/j.clysa.2016.11.003

Muratori, M., Zubieta, E., Ubillos, S., González, J., \& Bobowik, M. (2015). Felicidad y Bienestar Psicológico: Estudio Comparativo Entre Argentina y España. Psykhe (Santiago), 24(2), 1-18. https://doi.org/10.7764/psykhe.24.2.900

Rivera, D., Cruz, C., \& Munoz, C. (2011). Satisfacción en las relaciones de pareja en la adultez emergente: El rol del apego, la intimidad y la depresión. Terapia Psicológica, 29, 77-83. https://doi.org/10.4067/S0718-48082011000100008

Roa, J. (2017). La Innovación Social Educativa (ISE) como herramienta metodológica para la búsqueda de una educación con sentido. Rev. Guillermo de Ockham, 15(1).

Sánchez, M., García, J, Valverde, M., \& Pérez, M. (2014). Enfermedad crónica: satisfacción vital y estilos de personalidad adaptativos. Clínica y Salud, 25, 85-93. http://doi.org/10.1016/j.clysa.2014.06.007

Segura, U., \& Calderón, C. (2019). Estudiantes felices: competencias docentes vs satisfacción estudiantil. In Crescendo, 5(10), 1.

Tschannen-Moran, M. (2014). Trust matters: Leadership for successful schools (2nd ed). San Francisco, CA: Jossey-Bass.

Van Manen, M. (2003). Investigación educativa y experiencia vivida. Ciencia humana para una pedagogía de la acción y de la sensibilidad. Barcelona: Idea Books.

Van Manen, M. (2014). Phenomenology of Practice. Meaning-Giving Methods in Phenomenological Research and Writing. California: Left Coast Press.

Veenhoven, R. (2001). Calidad de vida y felicidad: No es exactamente lo mismo, en G. De Girolamo (Ed.). Salud y calidad de vida. Torino: II Pensamiento científico.

Veenhoven, R. (2005). Lo que sabemos de la felicidad. In L. S. A. Garduno Estrada, Bertha y Rojas Herrera, Mariano (Ed.), Calidad de vida y bienestar subjetivo en méxico (pp. 17-56). México: Plaza y Valdés.

Vielma, J., \& Alonso, L. (2010). El estudio del bienestar psicológico subjetivo. Una breve revisión teórica. Educere, 14(49), 265-275.

Villanueva, J. (2012). La epojé y la reducción como acceso a la vida trascendental. Letras, 83, 118. https://doi.org/10.4067/S0718-10432013000200006

Viñals, A., \& Cuenca, J. (2016). El rol del docente en la era digital. Revista Interuniversitaria de Formación del Profesorado, 30(2), 103-114.

Zumaeta-Arista, S., Fuster-Guillen, D., \& Ocaña-Fernández, Y. (2018). El afecto pedagógico en la didáctica de la matemática - Región Amazonas desde la mirada fenomenológica. Propósitos y Representaciones, 6(1), 409-462. https://doi.org/10.20511/pyr2018.v6n1.200

\section{Copyrights}

Copyright for this article is retained by the author(s), with first publication rights granted to the journal.

This is an open-access article distributed under the terms and conditions of the Creative Commons Attribution license (http://creativecommons.org/licenses/by/4.0/). 